\title{
Котова С.Г. \\ Естественное право в Древнем Риме и возможность его применения в Российской Федерации
}

КрФ ФГБОУВО «Российский государственный университет правосудия»

(Россия, Симферополь)

doi: 10.18411/trnio-12-2021-179

\section{Аннотация}

В статье исследовано естественное право в системе права Древнего Рима, а также изучена возможноть сфер общественных отношений, в которых возможно его применение в Российской Федерации.

Ключевые слова: естественное право, гражданское право, право народов, римское право, ответственность малолетних, криптовалюта.

\section{Abstract}

The article examines natural law in the system of law of Ancient Rome, and also examines the possibility of spheres of public relations in which its application in the Russian Federation is possible.

Keywords: natural law, civil law, peoples' law, Roman law, juvenile responsibility, cryptocurrency.

Естественное право интересовало великие умы во все времена, так Цицерон утверждал, что «всем этим миром правит разум», как некое объективно существующее регулирование «природы», как обусловленный определенными закономерностями источник разумных и справедливых установлений и действий людей [3. с. 433-434]. Что можно представить, как определенный объективно существующий камертон, настраивающий как законодательство, так и право в целом. Без четкого понимания значения ius naturale правовое регулирование в государстве склонно замыкаться на самом себе, отрываясь от естественного развития и реальных насущных потребностей общества.

В Древнем Риме наряду с гражданским правом (ius civile) и правом народов существовала еще одна важная правовая система (ius gentium). В то время как гражданское право было внутренним установлением государства, «если мы что-либо прибавляем к общему праву или что-нибудь из него исключаем, то мы создаем собственное, т.е. цивильное право» [2], опираясь на усредненные показатели справедливости. Право народов предоставляло возможность упорядочивать отношения с жителями захваченных земель (перегринами), оно стало прародителем международного права, «...ius gentium - это то право, которым пользуются народы человечества» [2], так как является общим для всех людей. Гермогениян разъяснял: «Этим правом народов введена война, разделение народов, основание царств, разделение имуществ, установление границ полей, построение зданий, торговля, купли и продажи, наймы, обязательства за исключением тех, которые введены в силу цивильного права» [2].

Однако, в Древнем Риме достаточно четко представляли себе тот факт, что нормы права должны распространяться на большинство правоотношений в обществе, это говорит с одной стороны, что целый ряд отношений настолько уникальны, что находились за пределами законодательного регулирования, с другой то, что нормирование охватывает большинство подобных отношений в обществе.

Таким образом пробелы в праве - очевидный и весьма распространенный факт, который признавали античные юристы. Если сама правовая система ius civile ограничивает правовое регулирование, тогда надо искать мерило более объективного порядка, коим и стало естественное право. 
В Дигестах дано следующее понятие естественному праву: «...ius naturale - это то, которому природа научила все живое: ибо это право присуще не только человеческому роду, но и всем животным, которые рождаются на земле и в море, и птицам; сюда относится сочетание мужчины и женщины, которое мы называем браком, сюда же порождение детей, сюда же воспитание; мы видим, что животные, даже дикие, обладают знанием этого права» [2].

Дело в том, что многие отношения в обществе настолько индивидуальны, такие как семейные, например, что приведение их общему знаменателю возможно только по внешним показателям или на этапах трансформаций. Например, правовое регулирование института брака существовало лишь на начальном этапе при его заключении, а также на этапе его завершения. В общих чертах указывалось, что происходит с имуществом супругов и основной вектор патриархальной направленности данного союза. Во всех остальных вопросах, каждый глава семейства сам выстраивал правила своей семьи, которые признавались правом, но не имели мер ответственности, установленных государством за их нарушения. Надо сказать, что это явление, конечно, может повлечь серьезные злоупотребления, но тем не менее больше подходит таким отношениям по своей сути.

Зачастую при рецепции, часть правового регулирования просто игнорируется в виду либо неудобности, либо непонятности для реализации в правоотношениях. Как произошло с институтом права частной собственности в Советском Союзе, так сейчас всячески вытесняется из правового блока система естественного права. Однако, общество развивается, появляются новые неизвестные для регулирования отношения, например, обращение криптовалют. Очевидно, что данную платежную систему нельзя назвать деньгами по той причине, что в связи с повышенной важностью к данному инструменту его занормировали так, что людям уже не всегда выгодно пользоваться ими. Криптовалюты сравнивали с ценными бумагами, но и это регулирование сопряжено с требованиями сложных регистраций их эмитентов, поэтому с практической стороны оно тоже не подходит для определения понятия данного явления. Криптовалюта появилась как естественное требование времени в высокой оперативности, упрощений в обращении, поэтому установка мораториев на данный институт останавливает развитие общества в экономическом направлении. Система естественного права уже регулирует данные отношения в ряде стран исходя из признания правовых последствий сделок, заключенных с использованием криптовалюты.

На самом деле, в правовом регулировании Российской Федерации в некоторых вопросах методы воздействия на правоотношения. Связано это с регулированием мелких сделок с участием малолетних. Лица от шести до четырнадцати еще не полностью правосубъектны, чтобы нести какую-либо ответственность, однако, в соответствии с ч.2 ст.28 Гражданского кодекса Российской Федерации [1], мелкие сделки, а это значит, последствия таких мелких договорных отношений, в которые они вступают признаются правом. Фактически данные отношения нельзя считать полностью урегулированными действующим законодательством, так как ответственности несовершеннолетние не несут, понятно, что есть ответственность родителей материального плана за проступки своих детей, но как быть с неумышленными нарушениями, в данном случае, в большей мере риск несет контрагент, например, продавец в магазине, который в данном случае вынужден заранее переспросить, например, достаточно ли несовершеннолетнему дали денег для покупки, достиг ли он специального возраста для покупки отдельных категорий товаров. То есть, в сущности, отношения, которые складываются между продавцом и покупателем-малолетним урегулированы естественным правом, то есть, если данная правовая трансакция прошла успешно, ее последствия считаются правовыми, малолетнему передается право собственности на соответствующий товар. Если случилась мелкая конфликтная ситуация, то преодолеть ее с помощью права не выйдет, так как сам по себе малолетний еще не субъект права. 
На наш взгляд, использование естественного права в целом имеет положительное значение, однако, есть проблемы с его пониманием. Исходя из нормы, обозначенной в Дигестах (D.1.1.1.3), получается, что субъектами таких отношений являются как равноправные люди, так и животные. Если с людьми мы за две тысячи лет осознали ценность подобной нормы, хотя вопросы разного рода дискриминаций еще встречаются, то готовы ли мы воспринять на данном этапе развития общества правосубъектность животных?

Таким образом, естественное право является ценным правовым механизмом, который способствует развитию общественных отношений, укреплению легитимности действующих правовых институтов, так как переключает бремя ответственности с государства на самих участников отношений, предоставляя им большую меру свободы действий.

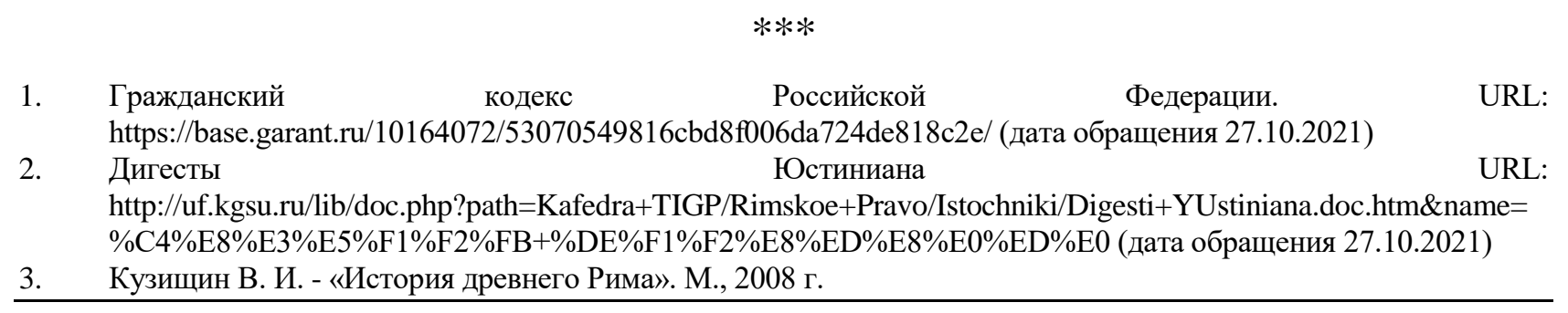

\section{Крахмалев Н.С. \\ Международный опыт банкротства граждан}

Волгоградский государственньй университет

(Россия, Волгоград)

doi: 10.18411/trnio-12-2021-180

\section{Аннотация}

В данной статье рассмотрен международный опыт в сфере банкротства физических лиц. Выгодные условия, особые процедуры и цивилизованное урегулирование задолженности физических лиц по кредитам.

Ключевые слова: банкротство, несостоятельность, долг, законодательство, ответственность, кодекс о банкротстве, кредит, банк.

\section{Abstract}

This article examines the international experience in the field of bankruptcy of individuals. Favorable conditions, special procedures and civilized settlement of individuals' debt on loans. bank.

Keywords: bankruptcy, insolvency, debt, legislation, liability, bankruptcy code, credit,

В зарубежном опыте процедуры банкротства потребителей уже давно активно используются как механизм цивилизованного урегулирования задолженности физических лиц по кредитам.

Международный опыт в сфере банкротства физических лиц показывает, что если имущества гражданина недостаточно для единовременного погашения долга по выданному кредиту, банку выгоднее не забирать у должника последнее имущество, фиксируя в документах дефолт по выданному кредиту, а помочь должнику сохранить имущественный и социальный статус с возможностью реструктуризации его задолженности.

Во многих странах в действующем гражданском законодательстве существуют институты банкротства физических лиц, не являющихся предпринимателями, поскольку «исторически теория конкурсного процесса формировалась на основе того, что несостоятельным (банкротом) может быть объявлено только лицо физическое». 